\title{
PRODUCTION OF BISCUITS WITH HIGHER NUTRITIONAL VALUE
}

\author{
Daina Kārkliṇa, Ilga Gedrovica, Marina Reca, and Maija Kronberga
}

Faculty of Food Technology, Latvia University of Agriculture, Lielā iela 2, Jelgava, LV-3001, LATVIA daina.karklina@ Ilu.Iv

Communicated by Inga Ciproviča

\begin{abstract}
Biscuits were prepared by substituting wheat flour with Jerusalem artichoke powder, which is a widespread plant, and powder of cacao bean shells, which is a by-product of the cocoa bean refining process. Both of these were added to biscuit dough. Biscuits were analyzed for physical and chemical parameters. The results indicate that both materials contain highly valuable ingredients for production of a new type of biscuits. Jerusalem artichoke powder and cocoa shells contributed to fibre content, and the content of protein and fat changed. Also, the hardness and colour of the biscuits differed compared to the control.
\end{abstract}

Key words: biscuits, fortification, Jerusalem artichoke and cocoa bean shells.

\section{INTRODUCTION}

The relation between food and health has had an increasing impact on food innovation, due to the popularity of the concept of functional food. The practise of using nutrition knowledge at the food product level to improve health of the consumer forms the general concept of functional foods.

Many overweight people often have a craving for sweets and find it difficult to abstain from eating high calorie products. Therefore, new sweets need to developed, which have all the health-promoting properties of foods, but with taste and look like the conventional foods that are popular and regularly consumed by the public.

Biscuits are the most popular bakery products worldwide. Biscuits are ready to eat, cheap and conventional food. Different types of biscuits contain high contents of fat, sugar and calories, but they are low in fibre, vitamins, and minerals. Thus, they do not correspond to the rules of a healthy diet. Biscuits have a longer shelf life, good taste and are accepted as snacks in all age groups. Therefore, biscuits are considered as a good product for fortification and nutritional improvement. The main ingredient generally used for biscuits is high quality wheat flour with other ingredients, such as butter, margarine, sugar, eggs, milk and some plant species.

Legumes, fruits and other cereals have been widely recognized as important sources for fortification of wheat-based traditional bakery products, such as biscuits. Improvement of the nutritional quality of wheat-based biscuits through fortification with other materials of different plants has been investigated in several studies (Preedy et al., 2011).
There are several innovative ways to produce healthy and low calories biscuits. The fortification of biscuits with different kinds of nutrients is a common trend.

Protein fortification of biscuits is of current interest, because of increasing awareness of consumers towards health. Protein-fortified biscuits contains nutrients in concentrated forms. Protein-fortified biscuits can be prepared from composite flours, such as wheat flour fortified with soy, cottonseed, peanut, corn germ flour or mustard flour. Soybean is an excellent source of protein. It contains $35-45 \%$ of all essential amino acids required for proper growth and maintenance of the body. Rice bran is rich in soluble fibre like $\beta$-glucan, pectin, and gums. Biscuits made with substitution of soy flour and rice bran up to $15 \%$ each are nutritionally more superior to that of whole wheat flour biscuit (Mishra and Chandra, 2012).

Pigeon pea (Cajanus cajan L.) grain is also mention a potential source of protein. Biscuits of acceptable quality can be prepared by substituting wheat flour with up to $15 \%$ pigeon pea flour or up to $10 \%$ pigeon pea by-product flour (Tiwari et al., 2011). Biscuits containing 20\% defatted mustard flour were found to be nutritionally rich, but scored lower for sensory quality than biscuits prepared from $15 \%$ defatted mustard flour (Tyagi et al., 2007).

The addition of dietary fibre to standard products changes the texture, flavour and taste of final products. The incorporation of a high amount of fibre in conventional foods often causes disruption of the wheat flour starch-gluten matrix and thus negatively affects dough properties.

The most common source of dietary fibre in bakery products has been bran from various cereals. Bran of wheat, rye, 
oat and rice is commonly used for the production of wholemeal products, including cookies, breads, muffins and extruded snacks (Ktenioudaki and Gallagher, 2012).

One of the less investigated plant products is Jerusalem artichoke (Helianthus tuberosus L). Jerusalem artichoke (Heliantus tuberosus L.) tubers are known to be a health-promoting source. They contain inulin instead of starch as a carbohydrate reserve. Inulin and its degraded product oligofructose are the main compounds of interest in the food industry as functional food ingredients and low-calorie food materials. Many scientists have discovered that inulin has a beneficial effect on the gastro-intestinal activity stimulating reproduction of beneficial bacteria. Jerusalem artichoke powder made from Jerusalem artichoke roots also is a valuable product, rich in inulin, as well as vitamins and minerals (Praznik and Cieslik, 2000, Praznik et al., 2002, Cieslik et al., 2005). Powder of dried Jerusalem artichoke tubers is more convenient to store for a longer time and easier to use in technological processes. Jerusalem artichoke powder has lower moisture, protein, and fat content in comparison with high quality wheat flour, but the dietary fibre, sugars, vitamins, and minerals amounts are higher (Gedrovica, 2012). Powder of whole tubers of Jerusalem artichoke with high amounts of inulin could potentially be applied as a substitute of cereal flour in biscuits.

It has been suggested that cocoa shells can be a good source of dietary fibre, with reported values ranging from $21.3 \%$ to $45.9 \%$ of total dietary fibre as non starch polysaccharides. They also contain high amounts of fat $(6.87 \%)$ and protein (16.93\%) (Redgwell et al., 2002).

The aim of the present investigation was to evaluate the application of Jerusalem artichoke powder and cocoa bean shells in butter biscuit production.

\section{MATERIALS AND METHODS}

Raw materials used for butter biscuits were: dried Jerusalem artichoke powder, cocoa bean shell powder, commercial high quality wheat flour, sugar, fresh chicken eggs, butter, vanilla sugar, and baking powder (Table 1).

Dried Jerusalem artichoke powder, cocoa bean shell powder, high quality wheat flour and other ingredientss were used as raw materials. Part of the high quality wheat flour was replaced by Jerusalem artichoke powder at concentrations of $10 \%, 20 \%, 30 \%, 40 \%$ and $50 \%$ of the total flour amount and by cocoa bean shell powder at concentrations of $2.5 \%, 5.0 \%, 7.5 \%, 10 \%$ of the total flour amount. Butter biscuits were baked in an electric oven at $210{ }^{\circ} \mathrm{C}$ for 15 min, and cooled for 30 minutes. After cooling till room temperature, the samples were used for further studies. As control samples, biscuits were made of high quality wheat flour, and other ingredients required by the recipe in the same quantities.

The determined physical-chemical parameters and methods used for analysis are summarized in Table 2.
Table 1

PROPORTIONS OF VARIOUS INGREDIENTS USED IN BISCUIT PREPARATION

\begin{tabular}{lc}
\hline \multicolumn{1}{c|}{ Ingredients } & Quantity of raw materials \\
\hline Wheat flour/blend of wheat and powder & $100 \mathrm{~g}$ \\
Sugar & $44.6 \mathrm{~g}$ \\
Eggs & $17.7 \mathrm{~g}$ \\
Butter & $66.3 \mathrm{~g}$ \\
Baking powder & $2.17 \mathrm{~g}$
\end{tabular}

Table 2

ANALYSIS METHODS USED FOR TESTING EFFECT OF ADDITION OF JERUSALEM ARTICHOKE POWDER AND COCOA BEAN SHELL POWDER TO BISCUITS

\begin{tabular}{l|ll}
\hline No & \multicolumn{1}{|c|}{ Indices } & \multicolumn{1}{c}{ Method, standard or device used } \\
\hline 1. & Moisture, $\%$ & ISO 6496:1999 \\
2. & Fats, g. $100 \mathrm{~g}^{-1}$ & $\begin{array}{l}\text { Soxhlet method, AOAC 2003.06; ASN } \\
3414\end{array}$ \\
& & Kjeldahl, method ASN 3108; ASN 3112, \\
3. & Proteins, g.100 & AACC 46-20; LVS EN ISO5983 - \\
& & 1;2005 \\
4. & Total dietary fiber, g.100 ${ }^{-1}$ & AOAC 2003.06;ASN 3414
\end{tabular}

The colour of biscuits with Jerusalem artichoke powder and cocoa bean shell powder was determined using a Trismulus colorimeter Color Tec PCM/PSM (Accuracy Microsensors, Inc.). The CIE Lab colour value included is based on $\mathrm{L}^{*}$ (lightness - darkness), a* (redness-greenness) and $\mathrm{b}^{*}$ (yellowness-blueness). Colours were measured on the surface of the biscuit slice by making at least ten readings in three replicates for each biscuit type.

Hardness of biscuit was determined using a texture analyzer TA.XT.plus (Stable MicroSystems Ltd.). The method is based on compression test (Pre-Test speed and Test speed were $1 \mathrm{~mm}$ sec-1, post-test speed was $10 \mathrm{~mm} \mathrm{sec}^{-1}$ ) using a HDP/3PB Three Point Bending Rig. The TA.XT.plus texture analyzer was equipped with a load cell of $50 \mathrm{~kg}$. The results were expressed as maximum force in Newtons. In these tests Trigger force was $0.04903 \mathrm{~N}$. The outcome was determined from approximately ten readings of tree replications for each biscuit type.

The SPSS 14.0 for Windows and Microsoft Excel for Windows 7.0 software were used for statistical analysis. Mean arithmetic value and standard deviation were calculated for the obtained results (Field, 2005).

\section{RESULTS}

The results of nutritional analyses are presented in Table 3 and Table 4. Incorporation of Jerusalem artichoke powder (JAP) and cocoa beans shell (CBS) considerably improved total fibre content of biscuits. In classical butter biscuits made of high quality wheat flour the dietary fibre content

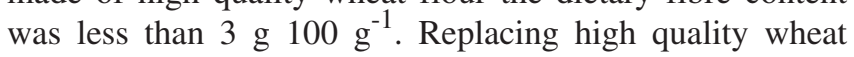
flour with Jerusalem artichoke powder, the amount of die- 
NUTRITIONAL CHARACTERISTICS OF JERUSALEM ARTICHOKE POWDER (JAP) FORTIFIED BISCUITS

\begin{tabular}{l|c|c|c|c|c|c}
\hline $\begin{array}{l}\text { Constitu- } \\
\text { ents }\end{array}$ & $\begin{array}{c}\text { Control } \\
\text { biscuit }\end{array}$ & $\begin{array}{c}\text { Biscuits } \\
\text { containing } \\
10 \% \text { of } \\
\text { JAP }\end{array}$ & $\begin{array}{c}\text { Biscuits } \\
\text { containing } \\
20 \% \text { of } \\
\text { JAP }\end{array}$ & $\begin{array}{c}\text { Biscuits } \\
\text { containing } \\
30 \% \text { of } \\
\text { JAP }\end{array}$ & $\begin{array}{c}\text { Biscuits } \\
\text { containing } \\
40 \% \text { of } \\
\text { JAP }\end{array}$ & $\begin{array}{c}\text { Biscuits } \\
\text { containing } \\
50 \% \text { of } \\
\text { JAP }\end{array}$ \\
\hline $\begin{array}{l}\text { Moisture, } \\
\%\end{array}$ & 1.21 & 1.08 & 1.12 & 1.24 & 1.23 & 1.26 \\
$\begin{array}{l}\text { Fats, } \\
\text { g 100g }\end{array}$ & 31.02 & 29.4 & 29.4 & 28.8 & 28.97 & 28.75 \\
$\begin{array}{l}\text { Proteins, } \\
\text { g 100 }\end{array}$ & 6.81 & 5.94 & 5.89 & 5.76 & 5.51 & 5.45 \\
$\begin{array}{l}\text { Total } \\
\text { dietary } \\
\text { fibre, } \\
\text { g 100 }\end{array}$ & 2.41 & 3.16 & 3.36 & 3.55 & 3.77 & 3.98 \\
$\begin{array}{l}\text { Inulin, } \\
\text { g 100 }\end{array}$ & 0 & & & & & \\
\end{tabular}

Table 4

NUTRITIONAL CHARACTERISTICS OF COCOA BEANS SHELL (CBS) FORTIFIED BISCUITS

\begin{tabular}{l|c|c|c|c|c}
\hline Constituents & $\begin{array}{c}\text { Control } \\
\text { biscuit }\end{array}$ & $\begin{array}{c}\text { Biscuits } \\
\text { containing } \\
2.5 \% \text { of } \\
\text { CBS }\end{array}$ & $\begin{array}{c}\text { Biscuits } \\
\text { containing } \\
5.0 \% \text { of } \\
\text { CBS }\end{array}$ & $\begin{array}{c}\text { Biscuits } \\
\text { containing } \\
7.5 \% \text { of } \\
\text { CBS }\end{array}$ & $\begin{array}{c}\text { Biscuits } \\
\text { containing } \\
10 \% \text { of } \\
\text { CBS }\end{array}$ \\
\hline $\begin{array}{l}\text { Moisture, \% } \\
\text { Fats, }\end{array}$ & 2.02 & 1.99 & 1.86 & 1.62 & 1.41 \\
g 100g & 24.32 & 25.46 & 26.20 & 26.83 & 27.64 \\
$\begin{array}{l}\text { Proteins, } \\
\text { g 100 }\end{array}$ & 5.24 & 5.29 & 5.32 & 5.38 & 5.46 \\
$\begin{array}{l}\text { Total dietary } \\
\text { fibre, g } 100^{-1}\end{array}$ & 2.9 & 3.16 & 3.58 & 3.94 & 4.22
\end{tabular}

tary fibre increased significantly $(P<0.05)$. Replacing wheat flour with $30 \%$ of Jerusalem artichoke powder, the dietary fibre content in $100 \mathrm{~g}$ of butter biscuits was $3.55 \mathrm{~g}$, and therefore, these biscuits can be called a "dietary fibre source".

In biscuits in which high quality flour was replaced with Jerusalem artichoke powder, the content of inulin increased significantly $(P<0.05)$. In butter biscuits there was no significant effect on moisture content $(P>0.05)$. An increased concentration of JAP in biscuits was associated with a lower fat and protein content, compared with the control sample

Total fibre content was higher and moisture content, lower, in biscuits with CSB. The protein and fat content of control biscuits was slightly lower compared with samples with $\mathrm{CSB}$, likely due to the high content of fat and protein in cocoa beans shells (Redgwell et al, 2002).

Changes of colour intensity $\left(\mathrm{L}^{*} \mathrm{a} * \mathrm{~b} *\right)$ in samples with JAP and CBS is demonstrated in Figures 1 and 2. The levels of colour component $\mathrm{L}^{*}$ show that samples with both powders were darker than control samples. The largest significant difference in samples with Jerusalem artichoke powder was in colour component $\mathrm{L}^{*}$ value. All biscuits containing the

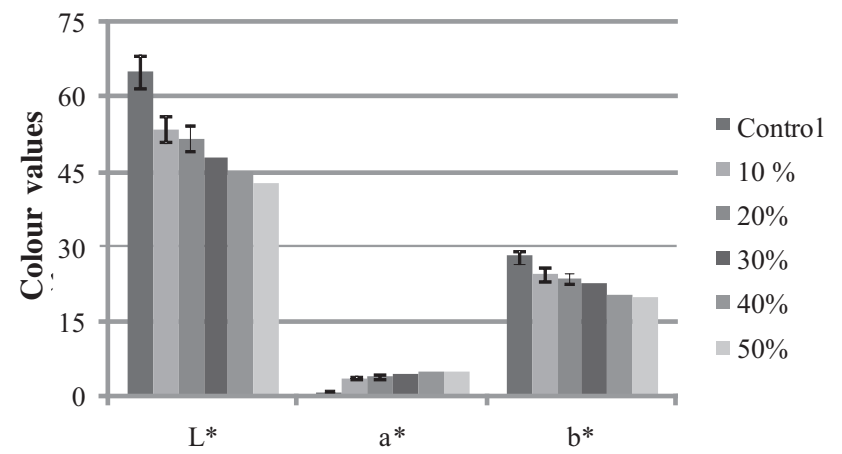

Fig. 1. Colour of biscuits with Jerusalem artichoke powder addition

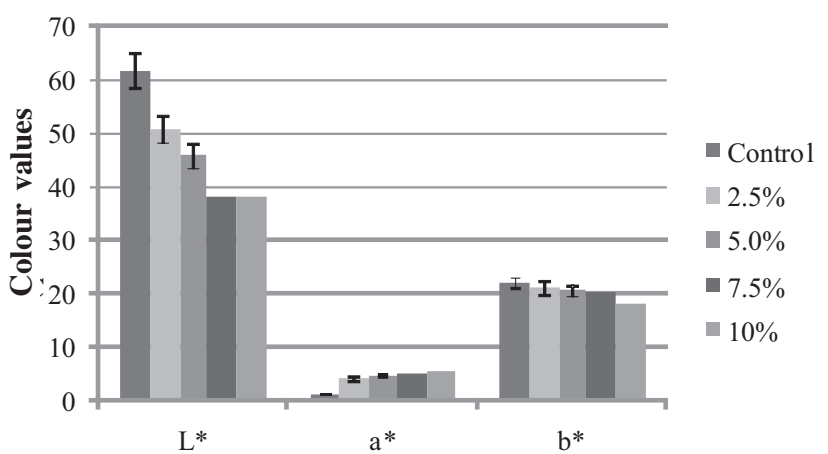

Fig. 2. Colour of biscuits with cocoa beans shell addition

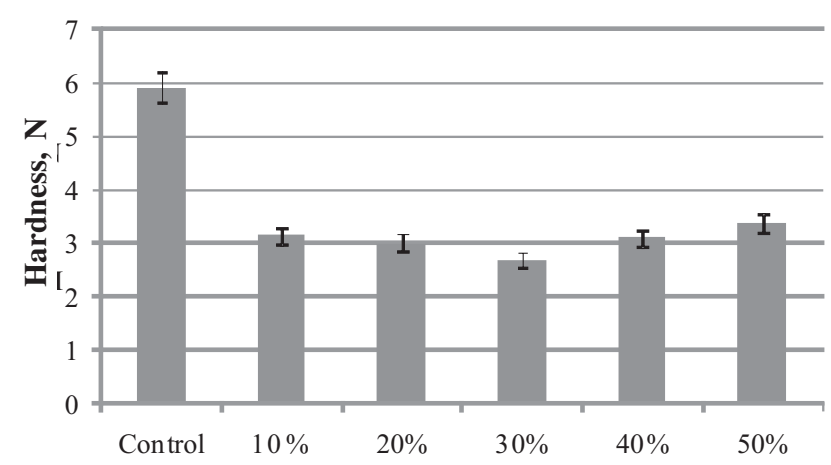

Fig. 3. Hardness of biscuits with Jerusalem artichoke powder addition

JAP or CBS powder gave lower $\mathrm{L}^{*}$ readings, indicating darker surface colour. In general, the $\mathrm{L}^{*}$ value decreased with an increase in amounts of substitute added.

Hardness of butter biscuits with JAP decreased by 25.2$39.3 \%$ (Fig. 3). The hardness of biscuits with CBS increased with increased CBS powder amount in composite flour biscuits (Fig. 4). The increase of hardness of biscuits with CBS powder is mainly due to higher proportion of protein (Gallagher et al., 2005).

\section{DISCUSSION}

The importance of dietary fibre in the human diet is widely accepted, and over many years extensive research has been undertaken on the enrichment of food products with fibre. 


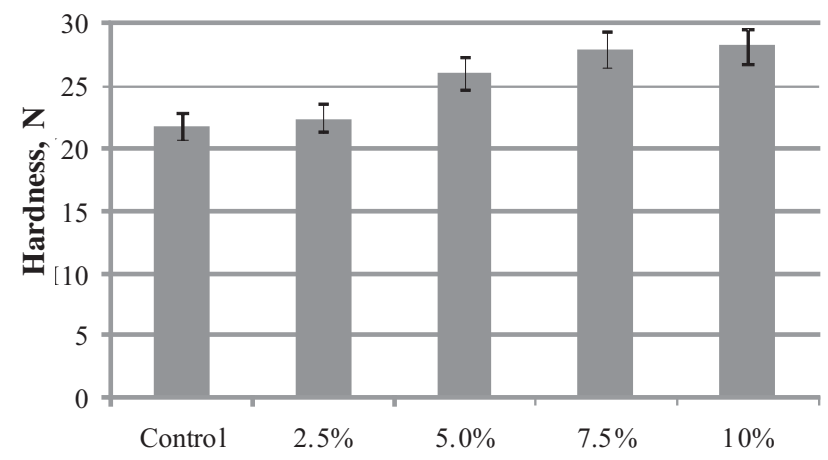

Fig. 4. Hardness of biscuits with cocoa beans shell

JAP and CBS powder additions in biscuit formulation had considerable effects on the physical-chemical properties of biscuits. In biscuits with Jerusalem artichoke and CBS powder, the nutritional value increased due to the content of dietary fibre increased. The study found that JAP and CBS can be successfully incorporated in biscuit dough. The study confirmed that traditional high fat and high sugar biscuits, which are not associated with healthy diets by most consumers, can be modified to produce a healthy alternative.

\section{REFERENCES}

Cieslik, E., Kopec, A., Praznik, W. (2005). Healthly properties of Jerusalem artichoke flour (Helianthus tuberosus L.). Electron. J. Polish Agr. Univ., 8(2), http://www.ejpau.media.pl/volume8/issue2/art-37.html (last accessed 8 December 2011).
Gallagher, E., Kenny, S., Arendt, E.K. (2005). Impact of dairy protein powders on biscuit quality. Eur. Food Res.Technol., 221(3-4), 237-243.

Gedrovica, I. (2012). Pastry products enriched with dried Jerusalem artichoke (Helianthus tuberosus L.) powder. Doctoral dissertation, Latvia University of Agriculture, Jelgava, Latvia.

https://lira.lanet.lv/F/RY96LQU4FXPSB2PHPLNJDE8PC9L7BIITKXP S3C22QKXH1G7C2S-20898?func=find-word\&scan_code=WTI\&rec_n umber=000277000\&scan_word=topinambura

Field, A. (2005). Discovering Statistics Using SPSS. London SAGE Publications, $771 \mathrm{pp}$.

Ktenioudaki, A., Gallagher, E. (2012). Recent advances in the development of high fibre baked products. Trends Food Sci. Technol., 20, 1-11.

Mishra, N., Chandra, R. (2012). Development of functional biscuit from soy flour\&rice bran. Int. J. Agricult. Food Sci., 2(1), 14-20.

Praznik, W., Cieslik, E. (2000). The composition of Jerusalem artichoke (Helianthus tuberosus L.) powders and their application in bakery products. http://www.kokkinias.com/fructan/admin/abstracts/pdf/praznik.pdf (last accessed 8 December 2011).

Praznik, W., Cieslik, E., Filipak-Florkiewicz, A. (2002). Soluble dietary fibres in Jerusalem artichoke powders: Composition and application in bread. Nahrung/Food, 46(3), 151-157.

Preedy, V.R., Warson, R.R., Patel, V.B. (2011). Flour and Breads and their Fortification in Health and Disease Prevention. USA: Academic Press Elsevier, 519 pp.

Redgwell, R., Trovato, V., Merinat, S., Curti, D,.Hediger, S, Manez, A. (2002). Dietary fibre in cocoa shell: Characterisation of component polysaccharides. Food Chem., 81, 103-112.

Tiwari, B.K., Brennan, C.S., Jaganmohan, R., Surabi, A., Alagusundaram, K. (2011). Utilisation of pigeon pea (Cajanus cajan L.) byproducts in biscuit manufacture. LWT-Food Sci. Technol., 44, 1533-1537.

Tyagi, S.K., Manikantan, M.R., Singh, O. H., Gurlen. K. (2007). Effect of mustard flour incorporation on nutritional, textural and organoleptic characteristics of biscuits. J. Food Eng., 80, 1043-1050.

Received 27 July 2012

\section{CEPUMU UZTURVĒRTĪBAS PAAUGSTINĀŠANA}

Rakstā apskatīts viens no variantiem, kā paaugstināt cepumu uzturvērtību, daḷu kviešu miltus aizvietojot ar škiedrvielām bagātu citu augu valsts materiālu. Pētījumā kā augu valsts materiāli ir izmantots topinambūra pulveris, aizvietojot 10, 20, 30, 40, 50\% miltu, un kakao pupu mizu pulveris, aizvietojot 2.5, 5.0, 7.5, 10\% miltu smilšu cepumu standarta receptūrā. Iegūtie rezultāti parādīja, ka, pievienojot topinambūra pulveri un kakao mizu pulveri, mainās cepumos esošais tauku un olbaltumvielu saturs, kā arī cietība un krāsa, kā arī paaugstinās šḳiedrvielu daudzums, salīdzinot ar kontroli. Cepumu fizikāli kị̄miskās izmaiṇas nav būtiskas un abus minētos augu materiālus var izmantot jauna tipa cepumu izgatavošanai. 